\title{
Religious Disagreement Is Not Unique
}

\author{
Margaret Greta Turnbull (Gonzaga University)
}

for Religious Disagreement and Pluralism

\author{
Eds. M. Benton and J. Kvanvig, Oxford University Press
}

\section{PREPRINT - PLEASE CITE PUBLISHED VERSION}

\begin{abstract}
In discussions of religious disagreement, some epistemologists have suggested that religious disagreement is distinctive. More specifically, they have argued that religious disagreement has certain features which make it possible for theists to resist conciliatory arguments that they must adjust their religious beliefs in response to finding that peers disagree with them. I consider what I take to be the two most prominent features which are claimed to make religious disagreement distinct: religious evidence and evaluative standards in religious contexts. I argue that these two features fail to distinguish religious disagreement in the ways they have been taken to. However, I show that the view that religious disagreement is not a unique form of disagreement makes religious disagreement less, rather than more, worrisome to the theist who would prefer to rationally remain steadfast in her religious beliefs.
\end{abstract}

\section{Introduction}

Religious disagreement seems, to many, to be a unique form of disagreement. ${ }^{\mathrm{I}}$ Numerous epistemologists have tried to understand what it means to rationally respond to specifically religious disagreement. ${ }^{2}$ In fact, some philosophers have argued that the

\footnotetext{
${ }^{I}$ This view is often held implicitly in the literature rather than explicitly. But see Matheson: "it might be thought that religious disagreement is special — that religious disagreement is importantly unlike other disagreements in science, politics, and philosophy more generally, and that such a difference renders religious beliefs immune from the defeating effects of discovered disagreement" (Matheson 2019, p. 8). Note that in this paper, I do not mean to implicate the oft-discussed Uniqueness Thesis about rationality (Feldman 2007) in using the term "unique." I use the term "doxastic attitude" to refer to the coarse-grained attitudes of belief, disbelief, suspension of judgment as well as degreed attitudes, including credences or degreed beliefs. Thanks to Charity Anderson for discussions of these issues and to Matt Benton and Jon Kvanvig for helpful comments on this paper.

${ }^{2}$ Perhaps some of the authors I discuss do not hold the view that religious disagreement is unique. Regardless, in this paper I will provide them reasons to refrain from adopting this view and will offer an
} 
distinguishing features of religious disagreement allow those who hold religious beliefs to hold on to their religious beliefs even in the face of disagreement. Even those who maintain that we must adjust our beliefs in response to learning of disagreement have argued that religious disagreement is an exception to this policy (for example, Bogardus 2013).

In this paper, I will argue that religious disagreement is not unique. There is no special problem of religious disagreement because the features which have been claimed to distinguish religious disagreement from other sorts of disagreement, on closer inspection, closely resemble features of numerous other sorts of disagreement. Further, I'll argue that recognizing that religious disagreement is not unique makes religious disagreement less, rather than more, concerning for the religious believer who would like to rationally hold on to her religious beliefs.

To ward off some immediate objections, I'll begin by clarifying the aims of my argument. I will not argue that the content of religious belief, the evidence we take to support it, the standards by which we evaluate it, and the ways agents come to hold it, are not, in certain ways, distinctive. I know of no other form of widely held belief on which some portion of our relevant evidence is taken to come from communication with the divine as it does in religious experience. Rather, I will argue that the form of religious disagreement is not unique. As I will argue, the structure of religious disagreements, despite the in many ways distinctive content of religious belief, is more like than unlike many other sorts of disagreement.

I will also avoid making claims about disagreement among epistemic peers. Stefan Reining (2016), Jennifer Lackey (2014), and others have shown that the question of who count as an epistemic peer in religious disagreements is a tricky one. The features of religious belief make it difficult to determine, for example, who shares my evidence in religious contexts on David Christensen's (2007) account of peerhood or who is as equally likely as I am to be mistaken about religious questions on Adam Elga's (2007) understanding of peerhood. I think we face similar problems in determining the presence

argument in later sections that given the non-distinctiveness of religious disagreement, religious disagreement is less concerning for religious believers than we otherwise might have thought it to be. See Benton (Forthcoming) and Frances (2015) for surveys of the epistemology of religious disagreement. 
of peerhood in just about every other context of disagreement, as Nathan King (2012) and Lackey (20I0) have recognized.

But I will avoid use of the technical term 'epistemic peer' in order to sidestep extant confusion about what that term might mean in religious contexts. I am interested in disagreements in which, upon learning that the disagreement exists, it is rational for us to carefully consider whether our religious beliefs might be mistaken and whether adjustment in our religious beliefs might be called for. ${ }^{3}$ I think focusing on these disagreements will allow us to approximate the target disagreements of interest to participants in the peer disagreement literature while setting aside determinations of whether agents engaged in religious disagreement are, in fact, epistemic peers, under the technical definition.

I will examine disagreements of this type about a specific religious proposition, t: God exists. In section 2, I will canvas two major ways that religious disagreement has been taken to be distinctive: religious evidence and evaluative standards for religious belief. I argue in section 3 that these features do not distinguish religious disagreement from other forms of disagreement. In section 4, I show that the loss of religious disagreement's distinctiveness need not worry the theist who would wish to rationally hold on to her religious beliefs in the face of religious disagreement. I conclude in section 5 .

\section{In What Ways Could Religious Disagreement Be Unique?}

Canvassing the literature on religious disagreement shows us that authors have taken two prominent features to make religious disagreement different from other forms of disagreement. First, I'll discuss how epistemologists have understood the evidence relevant to religious disagreement to be distinctive. Then, I'll consider discussions of the apparently peculiar standards by which we evaluate religious believers as credible and the role of these standards in religious disagreement.

Several philosophers have indicated that religious experience and its use in the justification of religious belief can make religious disagreement distinctive. These authors agree that in religious disagreement, unlike other forms of disagreement,

\footnotetext{
${ }^{3}$ However, I take these arguments to equally support the claim that other sorts of religious disagreement, such as disagreements between experts and novices, are not unique or distinctive.
} 
believers of $t$ sometimes have access to a form of evidence, religious experience, to which non-believers of $t$ do not and cannot have certain kinds of access. William Alston (I99I, Ch. 7) and Alvin Plantinga (2000, pp. 443-457, especially pp. 454) suggest that since religious believers have access to religious experience, this additional evidence can allow believers of $t$ to rationally hold on to $t$ in the face of challenges from religious pluralism. Reining (2016, pp. 408) argues that religious believers sometimes undergo perceptually unique religious experiences which involve "none of the standard senses." This evidence can allow believers of $t$ to justifiably hold on to belief in $t$ when they meet those who have not had such religious experiences and believe $\sim$ t. ${ }^{4}$ Similarly, Kirk Lougheed (2018, I84I90) uses Philip Wiebe's (2015) articulation of religious experience as a form of intuitive knowing to argue that believers of thave access to evidence which defies communication. This evidence then justifies them in holding on to belief in $t$ in the face of disagreement with those who do not have access to these incommunicable religious experiences. ${ }^{5}$ Tomas Bogardus notes that in cases of religious disagreement involving "believers who base their beliefs at least in part on private religious experiences they've had," his preferred Equal Weight view does not require individuals to adjust their beliefs in response to learning of the disagreement since this view only requires individuals who have access to the same evidence to adjust their beliefs (2013a, pp. I5). These authors seem to share a common view that in order to truly share one's evidence with a partner in disagreement, one must be able to articulate and communicate most, if not all, of the

\footnotetext{
${ }^{4}$ See also Kraft (2007, pp. 427-428) and Bergmann (2017, pp. 36-4I) for related arguments. Dormandy (2018) addresses the problem of weighting religious experience and similar sorts of evidence as compared to more readily communicable, public forms of evidence, in pursuit of resolving religious disagreement. Discussion of religious experience shares a common thread with discussions of religious disagreement and transformative experience in religious contexts. See De Cruz (2018, especially pp. 270). ${ }^{5}$ Van Inwagen (2OIO, pp. 26-27) flirts with a similar view. Lougheed (2OI8) also discusses the possibility that self-trust in the theist's own beliefs, the immediacy of the theist's beliefs, and the theist's ability to introspect on her own experiences may allow the believer of $t$ to remain rationally steadfast (2018, S2.I, S2.2, and S2.3 respectively). But Lougheed is right to point out that these routes to steadfastness are by no means unique to religious disagreement. Likewise, DePoe (2018, pp. 260) and Bogardus (2013a, pp. 15) argue that the religious believer may be in a position to "just see the truth of their religious views" (Bogardus 20I3a, pp. 15). However, both Bogardus and DePoe offer as their examples of this phenomenon nonreligious contexts where individuals can directly see that their beliefs are true. Clearly then, this route to steadfastness is not understood as being a unique feature of religious disagreement.
} 
content of one's evidence from experience. ${ }^{6}$ Further, since religious experience is a distinctive form of experience which resists this type of communication and articulation to those who have not had the experience, the common thread through these arguments holds it can be rational for those who have had religious experiences to go on holding on to their religious beliefs in the face of disagreement with non-believers.

Others have argued that the standards by which we epistemically evaluate religious believers make religious disagreement distinctive. As Frederick Choo notes rightly, "there is disagreement on what the relevant credibility-conferring features are when it comes to assessing religious propositions" (Forthcoming, p. 5). Members of different religious traditions as well as members of the same religious tradition often find it difficult to determine which qualities make reasoners reliable in religious contexts. Since determining how one should respond to disagreement involves assessing the reliability or credibility of the reasoner with which one is in disagreement, the peculiar evaluative standards in religious contexts are sometimes seen as making religious disagreement distinctive.

John Pittard (2OI4) offers an extensive argument for this distinctiveness of epistemic evaluative standards in religious contexts. I'll leave the rather intricate details of Pittard's argument to his own work, but briefly, his argument runs as follows. First, religious traditions often reject "standard theories of epistemic credentials" on which believers are viewed as generally reliable if they possess "analytic sophistication, thorough acquaintance with the publicly available evidence, certification by prestigious institutions... raw intelligence, freedom from corrupting bias, etc." (20I4, pp. 87). In the place of these standard theories of epistemic credentials, religious traditions substitute "non-standard theories of epistemic credentials" on which standard qualities do not contribute greatly to the reliability of religious reasoners and are replaced by distinctive qualities such as "love of one's fellow human beings, love and desire for God, humility, detachment from material possessions" etc. (2014, pp. 88-89). Further, Pittard argues that these non-standard theories of epistemic credentials are "self-favoring" (20I4, pp. 90). On self-favoring theories of epistemic credentials, according to Pittard, those who are not

\footnotetext{
${ }^{6}$ In what follows, I'll use the term 'incommunicable,' in the sense these authors seem to intend it, to indicate bodies of evidence, the majority of whose content cannot be articulated and communicated to those who have not had the religious experience.
} 
members of one's religious tradition are not viewed as being as epistemically reliable as those within it (2014, pp. 90). ${ }^{7}$

Similar to arguments making use of religious experience, Pittard argues that these distinctive features of evaluative standards in religious contexts allow religious believers to resist arguments that they must give up confident religious belief in the face of religious disagreement. Pittard notes that on Christensen's (2007) popular account of conciliatory responses to disagreement, "conciliatory pressure generated by a disagreement correlates with the strength of the independent reasons for trusting my disputant" (2014, pp. 84). But religious believers who hold these distinctive non-standard theories of epistemic credentials lack reason to trust their disputants since these nonstandard theories of epistemic credentials are self-favoring. So the conciliatory pressure generated by a disagreement with those outside of their religious disagreement will be negligible, concludes Pittard (2014, pp. 96).

We've seen that these two features, religious experience and evaluative standards, can be understood as making religious disagreement a particularly unique kind of disagreement, one in which its often rational for religious believers to hold on to religious belief in the face of disagreement.

\section{Religious Disagreement Is Not Unique}

But religious disagreement is not unique. The features of religious belief which I've just discussed do not justify the claim that religious disagreement is distinctive.

First, consider the claim that religious experience constitutes an at least partially incommunicable, private form of evidence, one which allows us to hold on to religious belief in the face of disagreement with those who have not had such experiences. To think that this feature of religious disagreement makes religious disagreement unique, we

\footnotetext{
${ }^{7}$ Pittard does not once use the term 'peer' in his paper, though he develops Christensen's (2007) conciliationism which is explicitly aimed at peer disagreement. However the target of his argument is clearly consistent with the target of the present work since though participants in these disagreements will eventually downgrade each other as reliable reasoners with respect to the subject of the disagreement, it is still possible and even likely that it is rational for them to carefully consider the reasoning behind their beliefs and to ask whether adjustment might be called for. This reflection will, in Pittard's understanding I take it, result in the downgrading of each other as reasoners.
} 
would need to think that other disagreements outside religious contexts do not have this feature. In other words, we'd need to think that non-religious disagreements seldom (if ever) involve one party possessing evidence whose content is mostly incommunicable and to which their partner in disagreement cannot gain access to.

Of course, it's obvious that many non-religious disagreements involve one party having access to evidence which the other party does not. Perhaps one party is an expert on the topic under disagreement and the other member is a novice who cannot access technical evidence. However, much of the literature on religious disagreement concerns disagreement between individuals who, other than the religious experience which forms a disparity between them, are roughly each other's epistemic equals (see especially, Reining 2016). To effectively argue that this type of religious disagreement is not distinctive, we need to find similar non-religious disagreements in which the individuals involved do not resemble an expert and a novice but instead are on a more equal epistemic playing field and yet fail to share relevant evidence.

Even given this narrower focus, it's easy to determine that in many non-religious contexts, one partner in disagreement often possesses evidence which is not possessed by the other partner in disagreement. Further, the content of this unpossessed evidence resists communication to the other partner even when the partners in disagreement are similarly well-informed. Alvin Goldman (20IO) notes that most of the time, sharing of evidence occurs at a different time than belief acquisition. As Goldman puts it, "one often forgets even past observations that play a lively causal role in belief acquisition. These now-forgotten observations are relevant to the current justificational status of a belief that has been preserved over time, but they are not available for 'sharing' when asked for one's evidence" (2010, pp. $2 \mathrm{II}-2 \mathrm{I} 2){ }^{8}$ And even if a particular disagreement does not, in fact, involve evidence which one has forgotten, the threat that one may have forgotten relevant evidence remains. Given the fallibility of our memory and our awareness of such fallibility, we can never be sure that we have, in fact, remembered all the evidence on which our belief rests. And so many of our disagreements, whether religious or not, easily involve evidence which is not possessed by one partner in disagreement and which

\footnotetext{
${ }^{8}$ Feldman (2004, pp. 232) and his followers hold the view that evidence consists only in those states which are occurrent or present to the awareness of the believer. But this view of evidence has been dismissed as implausible by numerous epistemologists, including McCain (2014, pp. 45-49).
} 
resists communication to the partner who does not have it. ${ }^{9}$ Reflecting on the fact that disagreement in any context often involves evidence which one has forgotten forces us to recognize that the incommunicable evidence feature of religious disagreement does not make religious disagreement distinctive. I'll now consider several objections to this argument.

First: perhaps we quite regularly forget pieces of evidence on which we base our beliefs, but surely we do not regularly forget crucial pieces of evidence. My response to this worry is twofold. First, there certainly are some disagreements in which we are unable to remember and therefore are unable to share crucial pieces of evidence relevant to our beliefs. In these cases, we have incommunicable evidence involved in non-religious disagreement and so we again find that religious disagreement is not unique.

Second, the evidence on which we base our beliefs is often quite fragmented. It is seldom just one piece of evidence which leads us to adopt a justified belief. Instead, there is often a host of pieces of evidence (and background beliefs) which result in our adopting a particular belief. My belief in the thesis of scientific realism, for example, is based on numerous pieces of evidence, as Goldman recognizes, including the rejection of numerous counterexamples I've considered, the weight I give to the opinion of other philosophers who agree and disagree with the view, the ways my intuitions bolster the premises in support of the view, and even my perception of my intellectual acuity at the time I originally considered the arguments for and against it (Goldman 20IO, pp. 21I). While forgetting just one small fragment of evidence may not always spell trouble for achieving some sort of evidential parity between members of a disagreement, forgetting even a few of these fragments may directly impact the belief's justificatory status. Forgetting why I've rejected just one particular counterexample for example, to adapt an example from Goldman, could easily alter my attitude towards scientific realism from belief to disbelief (2OIO, pp. 2II)..$^{10}$ The fragmentation of evidence means that much of our evidence is crucial, however small it may appear to be. So the threat that our memory makes pieces of evidence, even small fragments of evidence, incommunicable, gives us

\footnotetext{
${ }^{9}$ Nathan King (2012, pp. 253-258) offers further arguments to this effect. Goldman (2010, pp. 210-212) provides further arguments for the incommunicability of evidence in religious and non-religious contexts alike which do not rely on the fallibility of memory which I do not have space to consider here.

${ }^{\text {Io }} \mathrm{My}$ suspicion is that forgetting a fragment of evidence will result in alterations to our doxastic attitude even more often when we consider degreed doxastic attitudes like credences.
} 
reason to think that important, incommunicable evidence is a feature of quite a decent amount of our disagreements.

But perhaps religious disagreement is still distinctive, says the objector, even given Goldman's worries about memory and evidence sharing. In scientific contexts, the objector points out, we take great pains to share our evidence, such that it is virtually impossible that we have forgotten any of the evidence relevant to our belief in scientific hypotheses and theories. So we can communicate our evidence in the contexts of scientific disagreements. And religious disagreement is distinctive because in religious disagreements, we cannot communicate the portions of our evidence which come from religious experience. ${ }^{\text {II }}$ But this line of objection fails to show us that religious disagreement is distinctive. Instead, it seems to provide an argument that scientific disagreement is distinctive. ${ }^{\mathrm{I}}$

The problems for evidence-sharing articulated by Goldman apply to our disagreements regardless of subject matter. Evidence which cannot be shared can feature in disagreements about the weather, morality, religion, and past events alike because the fallibility of memory can strike in the context of any subject matter. If the objector is correct that these memory-related problems do not occur in scientific contexts, then this will be the exception to our worries about evidence-sharing, not the rule. Perhaps scientific disagreement is distinctive. I am not concerned with such an argument here. However, Goldman's argument that our capacity to remember and communicate relevant evidence is faulty shows us that problems of evidence access and communication are not unique to religious disagreement.

Consider another objection. Perhaps religious disagreement is distinctive not because of the form of the evidence provided by religious experience, but because of this incommunicable evidence's content. ${ }^{13}$ Members of the New Atheism coalition, for

\footnotetext{
${ }^{11}$ Lougheed (2018, pp. I87) discusses a similar objection.

${ }^{\mathrm{I} 2}$ I'll note in passing that I'm unconvinced that the premises of this argument are true. See Turnbull (20I9, Ch. 2) for an argument that evidence sharing in scientific contexts is not as straightforward as is often assumed.

${ }^{13}$ Relatedly, it might be that religious disagreement is distinctive not just because of the form of religious evidence, but because of the type of claim involved in $t$. Perhaps religious disagreement is distinctive because it involves affirming the existence of a divine being, on which the entire religious belief structure depends, on the basis of this evidence which only believers of $t$ seem to have good access to. But this
} 
example, seem to understand religious experience to be akin to wish-fulfilling projections that have more in common with untrustworthy hallucinations than perceptual experiences which have been publicly proven to be generally reliable. Perhaps religious disagreement is distinctive because it involves an exceptionally untrustworthy source of evidence.

However, this objection misses the mark given the type of disagreement I've identified as the type of disagreement of interest to this paper and to authors in the literature on religious disagreement. If you hold that religious disagreement is distinctive because religious experience is such an untrustworthy source of evidence, it won't be rational for you to consider carefully whether your beliefs are mistaken and whether adjustment in your doxastic attitude towards $t$ might be called for when you, the non-believer of $t$, find yourself in disagreement with a religious believer about $t$. You view religious experience as so wildly unreliable that those who trust it are not the kind of people whose beliefs you take seriously in the first place. So if you hold that religious disagreement is distinctive because religious experience is exceptionally untrustworthy, you won't find any of the discussions in which I'm intervening to be plausible in the first place.

But even if religious disagreement is not distinctive in this way, it might be that nonstandard, self-favoring evaluative standards make religious disagreement distinctive, as Pittard suggests. Again, to defeat the claim that religious disagreement is unique, I'll argue that in non-religious contexts, we can readily find non-standard, self-favoring evaluative standards at play. In these contexts, as in religious contexts, individuals reject common credentials of epistemic reliability (such as terminal degrees, raw intelligence, and the other qualities Pittard lists) and embrace non-standard sets of evaluative standards which are self-favoring, which are "unlikely to give an adherent of the religious belief system of which the [standards are] a part a reason for thinking that those who

objection also fails to distinguish religious disagreement from other sorts of disagreement. Moral disagreement often includes disagreement about the existence of certain mind-independent moral norms. So moral disagreement can involve disagreement about weighty ontological claims. And it is often somehow apparent to some parties in disagreement that these independent, static moral norms exist (for example, absolutists about morality) and not at all apparent to other parties in moral disagreement that such moral norms exist (for example, certain relativists about morality). The evidence for the existence of these moral norms also often seems to be based in the sorts of moral intuitions which cannot readily be articulated and transferred to other members of disagreement. Thanks to Matt Benton for encouraging me to consider this version of the objection. 
dispute the belief system are as epistemically qualified as those who accept it" (Pittard 2014 , pp. 87, 90). ${ }^{14}$ While individuals in these non-religious contexts will not use nonstandard, self-favoring evaluative standards of the same content as standards in religious contexts, these non-religious standards will share the same structural features of being non-standard and self-favoring as those invoked in religious disagreement.

We can find non-standard, self-favoring evaluative standards being used in moral and political contexts. ${ }^{15}$ First, consider moral disagreement and the evaluative standards being invoked to assess the reliability of reasoners in moral contexts. I propose that the evaluative standards in these contexts are non-standard. While the set of evaluative standards in moral contexts might include standard credentials, I think we rely more heavily on non-standard credentials, including awareness of the personal needs and desires of other agents, integrity, compassion, and a sense for the balance between justice and mercy in assessing moral reasoners. ${ }^{16}$ In addition, these credentials are often selffavoring..$^{17}$

For illustration, take Alex Rosenberg's (2017) discussion of disputes over the morality of honor killing in Eastern cultures. Persons who hold that honor killing is morally impermissible are often appalled that some cultures permit the practice. Similarly, those who hold that honor killing is morally permissible can readily view those outside their moral belief system as thoroughly failing to appreciate the social importance of honor. Those who are of the belief systems which hold that honor killing is morally impermissible will be unlikely to count as reliable moral reasoners those who are of belief systems on which honor killing is morally permissible. ${ }^{18}$ So we can see how in moral

\footnotetext{
${ }^{14}$ Pittard also argues that these evaluative standards involve "opaque" epistemic credentials. According to Pittard, "a credential C proposed by religious belief system B is opaque just to the extent that there is no reliable way to tell whether someone possesses $C$ if one does not know whether this person accepts the claims of B" (2014, pp. 90).

${ }^{15}$ Thanks to Harrison Lee for helpful discussion about this issue.

${ }^{16}$ See Schwitzgebel \& Rust (2014) for confirmation of the view that the very most relevant standard credentials do not guarantee moral character. This realization should encourage us that non-standard credentials are needed to assess the trustworthiness of moral reasoners.

${ }^{17}$ Elga (2007, pp. 492-494) is in agreement with me.

${ }^{18}$ The evaluative standards at play here also seem to involve opacity, in Pittard's terms. For example, those who hold the belief system on which honor killing is impermissible will likely only be able to confidently judge as compassionate those who share their belief system.
} 
disagreement, evaluative standards which are non-standard and self-favoring are at least sometimes invoked.

Similarly, in political contexts, we can find non-standard, self-favoring evaluative standards at play. We frequently use non-standard credentials, such as a person's willingness to accept social responsibility, their ability to evaluate fairness, and to be sensitive to the rights of others in evaluating them as a political reasoner. Members of opposing political parties notoriously often refuse to recognize each other as reliable political reasoners. ${ }^{19}$ In the US, Republicans frequently decry their opponents' alleged insensitivity to matters of national security and lack of respect for the rights of private citizens in their decision-making and Democrats often regard their opponents across the aisle as being consistently insensitive to the needs of the poor and vulnerable.

A worry emerges. Both of the areas of disagreement in which I've just argued that nonstandard, self-favoring evaluative standards are invoked are areas of particularly contentious disagreement, involving the clash of whole belief systems and not merely the clash of a few propositions. Perhaps non-standard, self-favoring evaluative standards only help to make a new class of distinctive disagreements, one which includes religious disagreement among other sorts of broad, fundamental disagreement.

But even if my argument only results in the new classification the objector suggests, I've still accomplished the aim of the present argument. We've successfully moved from the claim that religious disagreement is a unique form of disagreement on its own to the claim that it resembles other forms of disagreement, though it does not resemble every other form of disagreement. And I think this result squares with some of our pretheoretic intuitions about the terrain of disagreements. In some ways, we expect to find disagreement in politics, ethics, religion, and perhaps philosophy to be fundamental and intractable in a way that disagreements about a simple proof in formal logic are not. Reflecting on the structure of moral and political disagreements shows us that since non-

\footnotetext{
${ }^{19}$ For related empirical research which suggests that members of opposing parties understand the issues of central importance to contemporary governance more and more divergently, see Pew Research Center (2019). For empirical support of the related claim that we broadly discount as reliable reasoners those whose political views differ from our own, see Marks et al. (2019).
} 
standard, self-favoring evaluative standards are invoked, religious disagreement resembles these forms of disagreement.

We can conclude that religious disagreement is not wholesale unique. The features which were used to argue that religious disagreement was unique do distinguish religious disagreement from some other forms of disagreement but they fail to justify the view that religious disagreement is unlike every other form of disagreement.

\section{Consequences for the Epistemology of Disagreement}

In this section, I will articulate what follows from the recognition that religious disagreement is not unique. In general, I think the consequence of accepting this view is that religious disagreement is much less worrisome to those who might wish to hold on to their belief or non-belief in $t$ after encountering the kind of disagreement I've been concerned with here. Anecdotally, I think many individuals tend to be quite comfortable holding on to their moral and political beliefs in spite of the fact that other well-informed individuals may disagree with them about moral or political issues. Religious disagreement is sometimes met with more concern, perhaps because some theists are themselves concerned by the incommunicability of some of the evidence on which they base their beliefs. Recognizing that religious disagreement is not unique helps to calm some of these worries.

But what of the arguments which hold that the allegedly distinct features of religious disagreement allow individuals to rationally maintain their beliefs in the face of religious disagreement? First, I'll consider the impacts of the view I've been defending for those who hold non-conciliatory views of disagreement, on which it is sometimes rational to hold on to your original beliefs after learning of disagreement. Then, I'll consider how my conclusion affects the arguments proposed by those who hold conciliatory views of disagreement, on which learning of disagreement requires me to adjust my original doxastic attitudes about the matter under disagreement.

Proponents of non-conciliatory views of disagreement need not be threatened by the view that religious disagreement is not unique. Proponents of non-conciliatory views of disagreement already hold that it can sometimes be rational to hold on to our original doxastic attitudes in the aftermath of disagreement and some of them have argued that 
incommunicable evidence in religious contexts can serve this role of making it rational to hold on to your original doxastic attitude towards t. Goldman and I have argued that we often find ourselves in disagreements in which we cannot communicate the content of our evidence in contexts outside of religious contexts. So in the aftermath of this argument, non-conciliationists who hold that incommunicable evidence can make it rational to hold on to your original doxastic attitude in the face of disagreement will find the set of disagreements in which their preferred non-conciliatory response to disagreement applies to be widened to include cases in which we rely on our memory to assist us in evidence sharing.

Further, I think my argument can increase the dialectical advantage of nonconciliationists who believe t. Since non-theists can readily sign on to the idea that the failure of our faculties of memory may make some evidence incommunicable, the incommunicability of evidence from religious experience should seem less suspect to non-theists assessing the rationality of theists who hold on to their belief in $t$ in the aftermath of disagreement. As I foreshadowed earlier, this added advantage for nonconciliatory theists will only arise in discussions with non-theists who, unlike those of the New Atheist sort, do not, in a question-begging fashion, dismiss private religious experience based on their content. Nevertheless, recognizing that religious disagreement is not unique does not hinder the non-conciliatory position in the context of religious disagreement. Rather, this recognition increases the plausibility of holding on to belief in $t$ in the face of religious disagreement. ${ }^{20}$

Proponents of conciliatory views of disagreement find themselves in a bit more trouble given my conclusion that religious disagreement is not unique. This is because proponents of conciliatory views of disagreement like Pittard and Bogardus used the distinctive features of religious disagreement to argue that religious disagreement, in certain circumstances, could be an exception to the rule that we must adjust our doxastic attitudes on learning of disagreement. My sense is that some conciliationists want to

\footnotetext{
${ }^{20}$ Proponents of non-conciliatory views of disagreement, including Lackey (2010), are usually primarily concerned with the justificatory status of the original doxastic attitude towards the proposition under disagreement. Consequently, they are only indirectly concerned with the standards by which we evaluate our partners in disagreement. I have omitted discussion of the consequences of the non-distinctiveness of evaluative standards in religious contexts on non-conciliatory views of disagreement.
} 
have rational, confident religious beliefs in the aftermath of disagreement with nontheists. Unfortunately, I think my argument spells trouble for this sort of conciliationist.

First, if conciliationists accept my argument that incommunicable evidence arises in numerous disagreements outside of religious contexts, they will find themselves using their preferred conciliatory response to disagreement much less often than they might wish. Recall Bogardus's admission that in cases of disagreement where an individual relies on "private religious experiences," his preferred conciliatory view does not tell us whether conciliation is required, "for all the [Equal Weight] view says, it's reasonable to maintain one's religious beliefs in such cases of disagreement" (2013a, pp. 15). But if one's beliefs are based on incommunicable evidence in cases of disagreement across the board, when our memory fails to offer up the evidence we originally based our beliefs on, then the Equal Weight view and conciliatory views like it are perfectly compatible with steadfastly holding on to our original beliefs after disagreement.

Proponents of conciliatory views who wish to hold on to theistic belief in the face of religious disagreement are left with a problem. They must either come up with an argument that private, incommunicable evidence in religious contexts ought to be treated differently than other sorts of private, incommunicable evidence or they must accept that in many, many disagreements which involve the use of our memory to reproduce the evidence on which we base our beliefs, their preferred conciliatory view is perfectly compatible with holding on to our original doxastic attitudes rather than conciliating in response to disagreement.

Second, if conciliationists accept my argument that non-standard, self-favoring evaluative standards arise in non-religious disagreements, they will find themselves with a similar problem. Pittard has argued that non-standard, self-favoring evaluative standards can result in those who hold conciliatory views of disagreement rationally resisting the typical conciliatory advice to adjust one's belief in response to disagreement. I've argued that similar sorts of standards are at play in moral and political disagreements. So proponents of conciliatory views of disagreement seem, on Pittard's argument, to be committed to the idea that conciliating is not required in religious, moral, or political contexts. Now Adam Elga (2007, pp. 492-494) has already recognized that conciliatory views may not be committed to conciliationism in the contexts of these 
fundamental sorts of disagreement, so perhaps this consequence is not so concerning to some proponents of conciliatory views. However, perhaps there are other proponents of conciliatory views who want conciliationism to call them to conciliate in moral and political contexts, but not in religious contexts. If so, as I've argued, they will be forced to adopt a different argumentative tack, arguing that religious disagreement is the exception to the rule of conciliating on some other basis than non-standard, self-favoring evaluative standards.

\section{Conclusion}

I have argued that religious disagreement is not unique. The features which have previously been understood as making it distinctive, religious experience and nonstandard, self-favoring evaluative standards, have analog features in various nonreligious disagreements. Anecdotally, I've suggested that recognizing that religious disagreement is not in its own, unique class of disagreements will allow those who hold religious beliefs to find religious disagreement less threatening.

For non-conciliationists in favor of the incommunicable evidence justification for remaining steadfast in their doxastic attitudes, my argument also widens the scope of disagreements in which they may remain rationally steadfast and gives them an additional dialectical advantage in discussions of religious disagreements with those who do not share their religious beliefs. So discovering that religious disagreement is not unique makes religious disagreement less worrisome to non-conciliationists.

But the results are perhaps not quite so happy for all proponents of conciliatory views of disagreement. In the aftermath of my arguments, religious disagreement will, indeed, be less worrisome for conciliationists who are comfortable with the fact that their own conciliatory view will allow them to hold on to their original beliefs in a wide range of cases in addition to religious disagreements, including disagreements in which we rely on our memory to communicate the evidence on which we originally based our beliefs, as well as moral and political disagreements. For proponents of conciliatory views who are not happy with this consequence, new arguments will need to be advanced to argue that religious evidence and evaluative standards do not resemble the non-religious evidence and evaluative standards which I've argued that they do. Absent production of these arguments, we can conclude that religious disagreement is not unique and that this fact 
makes religious disagreement less, rather than more, worrisome for those who would wish to rationally hold on to their beliefs in the face of religious disagreement. 


\section{Works Cited}

Alston, W. (199I). Perceiving God: The Epistemology of Religious Experience. New York: Cornell University Press.

Benton, M. A. (Forthcoming). Religious Diversity and Disagreement. In M. Fricker, P. J. Graham, D. Henderson, \& N.J.L.L Pedersen (Eds.), The Routledge Handbook of Social Epistemology. New York: Routledge.

Bergmann, M. (20I7). Religious Disagreement and Epistemic Intuitions. Royal Institute of Philosophy Supplement, 8I, I9-43.

Bogardus, T. (20I3). Disagreeing with the (religious) skeptic. International Journal of Philosophy of Religion, 74, 5-17.

Choo, F. (Forthcoming). The Epistemic Significance of Religious Disagreements: Cases of Unconfirmed Superiority Disagreements. Topoi.

Christensen, D. (2007). Epistemology of Disagreement: The Good News. Philosophical Review, II6(2), I87-2I7.

De Cruz, H. (2018). Religious Conversion, Transformative Experience, and Disagreement. Philosophia Christi, 2O(I), 265-276.

DePoe, J. (2018). Hold on Loosely, But Don't Let Go. Philosophia Christi, 2O(I), 253-264.

Dormandy, K. (2018). Resolving Religious Disagreement: Evidence and Bias. Faith and Philosophy, 35(I), 56-83.

Elga, A. (2007). Reflection and Disagreement. Noûs, 4I(3), 478-502.

Feldman, R. (2007). Reasonable Religious Disagreements. In L. M. Anthony (Ed.), Philosophers Without Gods: Meditations on Atheism and the Secular Life (pp. 194-2I4). New York: Oxford University Press.

Feldman, R., \& Conee, E. (2004). Evidentialism: Essays in Epistemology. New York: Oxford University Press. 
Frances, B. (2015). Religious Disagreement. In G. Oppy (Ed.), Routledge Handbook of Contemporary Philosophy of Religion (pp. I80-19I). New York: Routledge.

Goldman, A. (20I0). Epistemic Relativism and Reasonable Disagreement. In R. Feldman \& T. Warfield (Eds.), Disagreement (pp. I87-213). New York: Oxford University Press.

King, N. (2012). Disagreement: What's The Problem? Or A Good Peer Is Hard To Find. Philosophy and Phenomenological Research, 85(2), 249-272.

Kraft, J.(2007). Religious Disagreement, Externalism, and the Epistemology of Disagreement: Listening to Our Grandmothers. Religious Studies, 43(4), 4I7-432.

Lackey, J. (2010). A Justificationist View of Disagreement's Epistemic Significance. In A. Haddock, A. Millar, \& D. Pritchard (Eds.), Social Epistemology (pp. 298-325). New York: Oxford University Press.

Lackey, J. (2OI4). Taking Religious Disagreement Seriously. In L. F. Callahan \& T. O'Connor (Eds.), Religious Faith and Intellectual Virtue (pp. 299-316). New York: Oxford University Press.

Lougheed, K. (2018). Is Religious Experience a Solution to the Problem of Religious Disagreement? Logos and Episteme, IX(2), I73-197.

Marks, J., Copland, E., Loh, E., Sunstein, C., \& Sharot, T. (2O19). Epistemic Spillovers: Learning Other's Political Views Reduces the Ability to Assess and Use their Expertise in Nonpolitical Domains. Cognition, I88, 74-84.

Matheson, J. (2019). Disagreement Skepticism and the Rationality of Religious Belief. In K. McCain \& T. Poston (Eds.), The Mystery of Skepticism: New Explorations (pp. 83-IO4). Boston: Brill.

McCain, K. (20I4). Evidentialism and Epistemic Justification. New York: Routledge.

Pew Research Center.(2019). Public's 2019 Priorities: Economy, Health Care, Education and Security All Near Top of List. 
Pittard, J. (2014). Conciliationism and Religious Disagreement. In M. Bergmann \& P. Kain (Eds.), Challenges to Moral and Religious Belief: Disagreement and Evolution (pp. 80-Ioo). New York: Oxford University Press.

Plantinga, A. (200o). Warranted Christian Belief. New York: Oxford University Press.

Reining, S. (2016). Peerhood in deep religious disagreements. Religious Studies, 52(3), 403419.

Rosenberg, A. (20I7). Can Moral Disputes Be Resolved? The New York Times. Retrieved from: https://opinionator.blogs.nytimes.com/2015/o7/13/can-moral-disputes-beresolved/

Schwitzgebel, E., \& Rust, J. (2OI4). The Moral Behavior of Ethics Professors: Relationships Among Self-Reported Behavior, Expressed Normative Attitude, and Directly Observed Behavior. Philosophical Psychology, 27(3), 293-327.

Turnbull, M. G. (2O19). Uncovering the Roots of Disagreement (Dissertation). Boston College, Chestnut Hill, MA.

van Inwagen, P. (2010). We're Right. They're Wrong. In R. Feldman \& T. A. Warfield (Eds.), Disagreement (pp. IO-28). New York: Oxford University Press.

Wiebe, P. H. (2015). Intuitive Knowing as Spiritual Experience. New York: Palgrave Macmillan. 